\title{
Fire management may hinder biodiversity
}

\section{... the question \\ is not whether \\ the land will \\ burn but when.}

\begin{abstract}
T earning to coexist with fire is one of the $\amalg$ greatest challenges to living in the West. In most of California, the question is not whether the land will burn but when. While there are few data on how fire affects the diversity of plants and animals, what we do know suggests that the way we manage fire is contributing to a decline in biodiversity. The loss of biodiversity statewide is a growing concern. With the decline of species and ecosystems comes degradation of the environment, and reduced sustainability of forests and rangelands.

Given concerns about fire management and biodiversity, exactly how we should change today's fire regime is being hotly debated.
\end{abstract}

\section{Forests}

California's most common fire-prone ecosystems are forests and chaparral, a shrubby habitat typical of the middle elevations of our state. When it comes to forests, almost everyone agrees that more than a century of fire suppression has led to the buildup of too much vegetation. While most forest fires in the Sierra Nevada were of low or moderate severity prior to the 19th century, today a greater proportion of forest fires are of high severity, according to the $1996 \mathrm{Si}$ erra Nevada Ecosystem Project Report to Congress. In other words, forest fires tend to burn hotter than they did historically.

Fire suppression has gradually changed the composition of California's forests, according to Richard Minnich of the Department of Earth Sciences at UC Riverside. The forests of the 1900s were a mosaic of vegetation patches-the types of plants varied depending on how recently a given patch had burned. This mosaic of patches supported a greater diversity of species, and the morerecently burned patches provided natural firebreaks. Today, the open old-growth, mixed conifer forests characteristic of, for example, the San Bernardino Mountains in the early 1900s are being.replaced by dense stands of young growth that are domi- nated by white fir, according to a study by Minnich and his colleagues.

\section{Chaparral}

While biologists also believe that today's fire regime is decreasing the biodiversity in chaparral, they disagree on how we should manage fire in this ecosystem. Minnich says the problem is too much fire suppression. "Fire control doesn't prevent fire in chaparral," he says. "It just postpones it until later in the season, when you get the worst kind of fire imaginable." As is the case in forests, says Minnich, these large fires convert chaparral from a mosaic of vegetation patches to a more homogeneous landscape with less species diversity and fewer natural firebreaks. He recommends letting chaparral burn during the spring, when the cooler air and greener vegetation can help control the fire's size and intensity.

In contrast, biologist Jon Keeley of Occidental College recommends continuing efforts to suppress fire in chaparral. People start so many fires in chaparral-about $95 \%$ of them - that the ecosystem burns more frequently than it did historically, says Keeley. While there is no evidence that fire suppression has decreased biodiversity in chaparral, a number of studies have shown that fires spaced only a few.years apart can promote the conversion of chaparral to nonnative grasslands, he says.

Researchers who did a recent study of fire occurrence records in Southern California chaparral concluded, "At this point, we find no evidence that fire suppression has significantly altered landscape-level fire regimes in Southern California chaparral. Suppression appears, in fact, to have been an essential factor in maintaining something approximating historical fire regimes in the face of increased fuel loads." This study was done by ecologist Susan Conard and research forester David Weise of the Riverside Forest Fire Laboratory (Pacific Southwest Research Station, Forest Service, U.S. Department of Agriculture), and they presented their findings at the 1996 Tall Timbers Fire Ecology Conference in Boise, Idaho.

\section{Reseeding}

Postfire treatments have also contributed to the decline in biodiversity in California's fireprone lands. For decades, people assumed that 
reseeding would control the erosion of burned slopes. Since the 1940s, agencies including the U.S. Forest Service (USFS) and the California Department of Forestry and Fire Protection (CDF) have reseeded vast areas of burned land with nonnative annual ryegrass, a fast-germinating and inexpensive annual. However, this nonnative grass can persist and displace native plants in chaparral and low-elevation forests, says Riverside Forest Fire Laboratory plant ecologist Jan Beyers. Furthermore, recent studies by Beyers and others show that postfire reseeding of slopes often does little to control erosion: in Southern California, winter rains can be so scanty that the seeds do not grow, while in Northern California heavy rains can come so soon after a fire that the seeds have not had time to grow. Even if reseeding were effective, in most cases it is not necessary because burned areas usually have enough viable native seeds in their soil, says fire ecologist Kevin Shaffer of the California Department of Fish and Game (CDFG).

\section{Fire management}

While a variety of agencies including county governments, the National Park Service and the Bureau of Land Management have jurisdiction over fire in California, the USFS and CDF are responsible for managing fire on most of the state's 100 million acres. National Forests account for about 20 million acres and so far this year nearly 600,000 of those acres have burned, which is about triple the 5-year average of 200,000 acres but is still less than the $900,000-$ some acres that burned in 1987. CDF is responsible for more than 40 million acres and as of early September more than 96,000 of those acres had burned, which exceeds the 5-year average of 84,000 acres.

Both the USFS and CDF have cut way back on reseeding. This year the USFS has reseeded about 7,200 acres, says Rob Griffith, USFS Regional Burned Area Emergency Rehabilitation coordinator. Instead of just automatically reseeding, the agencies sample the soil from burned areas and determine whether it contains enough viable native seeds to control erosion. If the agencies decide to reseed, they use native seeds when available; the USFS sowed local native grass on most (about 7,100 ) of the acres reseeded this year. If native seeds are not avail-

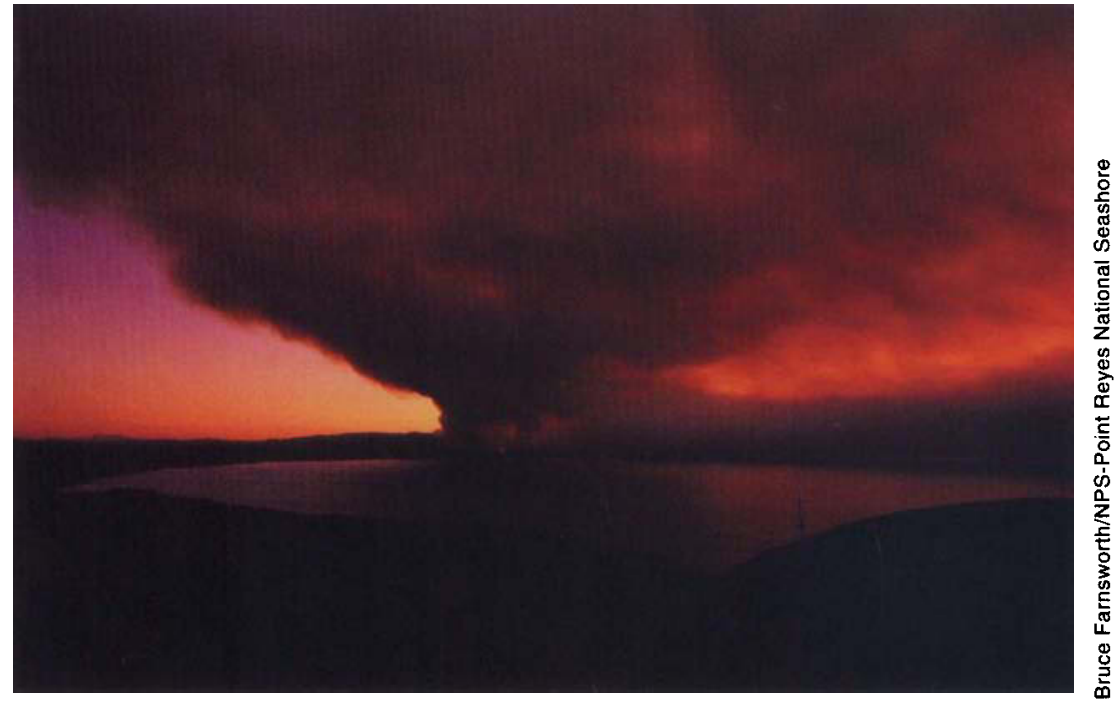

able, the agencies use nonnative annuals such as cereal barley that don't persist well in California. The agencies also use erosion-control alternatives such as mulching with rice straw; since rice is an aquatic plant, its straw has the advantage of being free of terrestrial weed seed.

Methods of clearing forests of the excess vegetation that can fuel

more intense wildfires in forests include selective logging, handcutting brush and prescribed burning. While all these methods are far less expensive than the cost of controlling wildfires, up to $\$ 25,000$ per acre, prescribed burning is the cheapest, at about $\$ 10-\$ 30$ per acre. In addition, the mechanical methods of clearing vegetation fail to mimic all of fire's ecological roles such as providing the heat necessary for germinating some types of seeds, says the CDFG's Shaffer. The USFS plans to increase prescribed burning in National Forests, and CDF also wants to increase prescribed burning over the current average of 40,000 acres per year. "We're not even in the right ballpark," says Ken Nehoda of the CDF Vegetation Management Program. "There are those who say we should be burning a million acres a year statewide."

However, managing fire on CDF land is easier said than done because the agency is responsible for the privately owned wildlands along the urban/wildland interface, where the conflict between people and native species is the greatest. Ever increasing numbers of people
The Point Reyes

National Seashore fire started October 3 and was declared controlled October 19, 1995. About 12,000 acres burned.

Above top, the Point Reyes' fire as seen from Chimney Rock Road across Drakes This was the first morning of the fire, before sunrise.

Above bottom, 2 days later, on Oct. 6, CDF firefighters battled the fire in Bay Laurel Grove, between Horse Trail and Sky Camp. Bay on Oct. 4, 1995. 


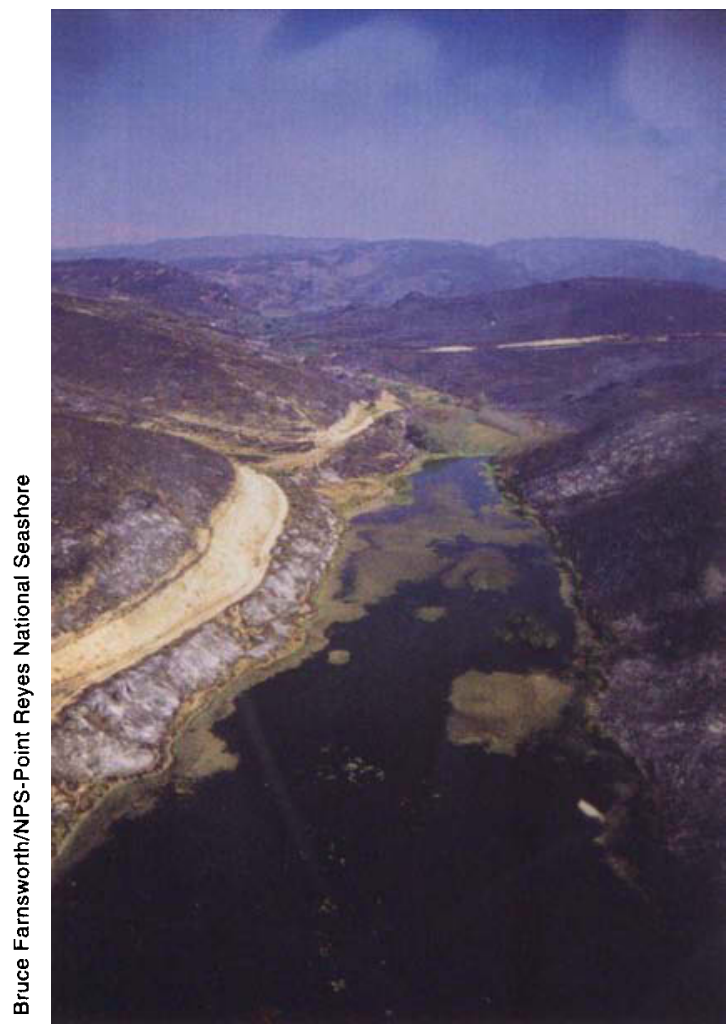

An aerial view showing White Gate Trail at center and Muddy Hollow Road at back right. The fire jumped the livestock pond in foreground.

Park rangers report that the stark landscape shown here is now fluorishing with new growth - both native and nonnative. Staff and volunteers are working to control nonnatives through several habitat restoration programs. are moving to fire-prone areas like the Sierra foothills and the interior chaparral in Southern California, and all of them are justifiably afraid of fire. "Large so-called catastrophic fires are a natural and inevitable feature of the California landscape," says Keeley. "I suggest that we recognize that and attempt to live within that constraint."

While the conflicts over how to manage fire in California are far from resolved, there is hope. "Agencies are starting to question their ideologies and the data behind them, and are allowing other agencies to work with them," says CDFG's Shaffer, who is also a member of the California Fire Strategies Committee, which coordi- nates private landowners, conservation groups and government agencies. "There's a lot more common ground than people had expected."

- Robin Meadows

\section{For further reading:}

Conard, Susan G. and D.R. Weise. "Management of Fire Regime, Fuels, and Fire Effects in Southern California Chaparral: Lessons from the Past and Thoughts for the Future." Tall Timbers Fire Ecology Conference. Boise, Idaho.

"Emergency Activity Report." California Department of Forestry and Fire Protection. 1996.

Haidinger, T.L. and J.E. Keeley. 1993. "Role of High Fire Frequency in Destruction of Mixed Chaparral." Madroño 40:141-147.

Minnich, Richard A., M.G. Barbour, J.H. Burk and R.F. Fernau. 1995. "Sixty Years of Change in California Conifer Forests of the San Bernardino Mountains." Conservation Biology 9:902-914.

Sierra Nevada Ecosystem Report to Congress. 1996. Wildland Resources Center Report Number 36. University of California, Davis.

\section{News from the recycling front...}

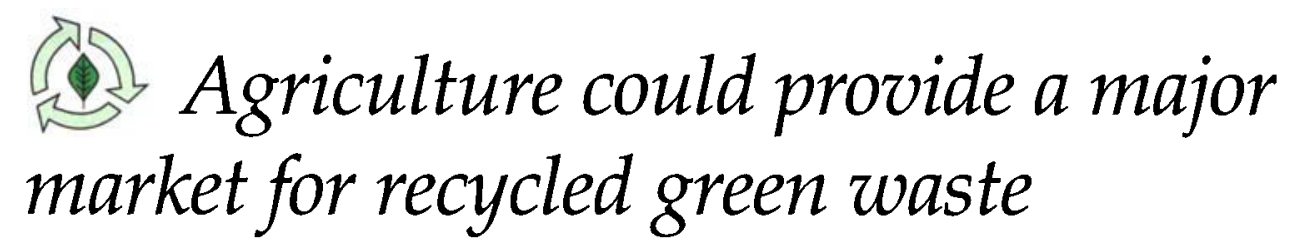

\footnotetext{
— very year, 10 million tons of grass clippings, tree leaves, limbs and twigs, vegetable cuttings and other organic wastes are produced in California. As the largest single component of the state's waste stream, recycling this "green waste" offers a significant opportunity for reducing inputs to landfills.

The most likely end user for the tons of compost and mulch produced with recycled green waste is the California agriculture industry. Whether green waste is beneficial to agricultural crops, and whether it is practical and economical have become questions for the UC Cooperative Extension.

In 1989, the California Legislature passed the Integrated Waste Management Act, which established a new approach for the management of California's waste stream. Assembly Bill 939 required a $25 \%$ diversion of the state's waste
}

from landfills by 1995 , and a $50 \%$ diversion by 2000.

Officials at the California Integrated Waste Management Board (CIWMB) estimate $3 \%$ of green waste is currently composted in backyards for on-site use. While community education programs like the one described in this issue (see p. 11) can increase this amount, the largescale reductions required by law necessitate an array of strategies. Many communities are turning to curbside collection and commercial recycling programs.

When the Integrated Waste Management Act became law, California was diverting $12.5 \%$ of its waste from landfills. Today, more than 500 communities, serving 20 million people, offer some curbside recycling; 173 of those, serving 8.5 million people, pick up green waste. CIWMB is still analyzing city and county 